\title{
Effect of Moringa Leaf Powder Supplementation on Some Biochemical Indices of Rats
}

\author{
Asogwa, Ifeyinwa $\mathbf{S}^{\mathbf{1}}$, Ani, Jane C, Omah, Esther C \\ ${ }^{1}$ Department of Food Science and Technology, University of Nigeria, Nsukka, Nigeria
}

*Corresponding Author: Asogwa, Ifeyinwa S, ${ }^{1}$ Department of Food Science and Technology, University of Nigeria, Nsukka, Nigeria

\begin{abstract}
This study evaluated the effect of moringa leaf powder (MLP) supplementation on some biochemical indices of rats. Twenty one day old male wistar albino rats were divided into five groups of five rats each. The first group (SOY) was fed with diet supplemented with $25.6 \%$ soybean flour, groups two to four were given MLP supplemented diets at $6.4 \%, 12.8 \%$ and $25.6 \%$ levels respectively and designated MORC, MORB and MORA. The fifth group (NORM) was fed with normal rat diet. All groups were fed with the diets for 14 days. MORA had the highest body weight gain 30.46g but this was not significantly $(p<0.05)$ different from body weight gain of MORB (29.38g) and NORM (25.02g). Evaluation of the liver function markers, revealed that there were significant $(p<0.05)$ reductions in alkaline phosphastase, direct and total bilirubin levels of the MLP fed rats relative to NORM. No significant $(p<0.05)$ differences were observed among the groups in the aspartate aminotransferase and alanine aminotransferase levels. There were no significant $(p<0.05)$ differences in the lipid profile parameters among the groups. Haematological analysis showed significant $(p<0.05)$ variations with MORA having lower PCV (38.40\%) and Hb $(13.64 \mathrm{~g} / \mathrm{dl})$ than NORM. Relative organ weights of the MLP fed rats were not significantly different from NORM expect for the heart weight where that for MORA was $(p<0.05)$ higher than the others. The result of this study shows that Moringa leaf powder could be safe for consumption and possesses some hepatoprotective properties as indicated by decrease in some liver function markers.
\end{abstract}

Keywords: Moringa leaf, growth, liver function markers, lipid profile, haematological parameters, supplementation, rats

\section{INTRODUCTION}

Moringa oleifera is a native the sub Himalayan tracts of India, Pakistan, Bangladesh and Afghanistan where it is used in folk medicine [1]. It is now grown in almost all parts of the world including Africa. M. oleifera is referred to as a "miracle tree" or a "wonder tree" [2] of significant socio economic importance because almost all parts of the plant is beneficial either as food or medicine. Moringa oleifera leaves are used as vegetables in the preparation of soup and sauces in Nigeria and in many African countries. Moringa leaves are however highly underutilized as it is consumed by the poor populace mainly during the dry seasons when the other preferred vegetables are out of season.

Numerous researchers have reported the high nutrient and phytochemical content of these leaves $[3,4]$. Moringa leaves are rich in protein; the dried leaves contain about $30 \%$ protein with all the 9 essential amino acids present in various amounts [5-7]. The leaves also contain rich amounts of vitamins and minerals [8,9]. Minerals contained in moringa leaves include iron, zinc, calcium, phosphorus etc [7]. Moringa leaves are rich sources of $\beta$-carotene (pro-vitamin A) and it has been reported that consumption of $8 \mathrm{~g}$ of the leaf powder will satisfy nearly all the vitamin A need for a child between 1-3 years [2]. Due to this rich content of nutrients and phytochemicals, it is used as an alternative source for nutritional supplements and growth promoters in some countries [10]. Moringa leaves have been used to treat anaemia in Nigeria and Philippines because of the high iron content [11].

The high phytohemcial content of moringa leaves have been reported. Moringa leaves contains polyphenols, saponins, alkaloids, steroids etc [12,11]. Phytochemicals are bioactive substances of plants that have been associated in the protection of human health against chronic degenerative diseases [13]. Phytochemicals in fruit and vegetables have proven effective in the prevention of certain chronic diseases [14]. This is because phytochemicals possess many biological activities for 
health promotion, such as antioxidant and free radical scavenging abilities, anti-inflammatory action, anticancer, anti-aging, and protective action for cardiovascular diseases, diabetes mellitus, obesity and neurodegenerative diseases [15]. The leaf extract is also capable of reducing hyperglycemia and dyslipidemia $[16,17]$.

Moringa leaves contains phytochemical having anticancer properties, it has been reported that the leaf extract had potent antiproliferative activity and apoptosis inducing capacity on tumor cell line [18] and it also increased the cytotoxicity of chemotherapy on pancreatic cancer cells[19]. The ethanol extract of the leaves prevented cyclophosphamide-induced micronucleus formation and DNA damage in mice [20]. The aqueous extract enhanced hepatic glutathione restoration [21]. Chadamas et al. [22] reported that tender pods decreased the formation of erythrocyte micronucleus in mice injected with 7,12 dimethylbenz (a) anthracene. It also demonstrated inhibitory potential against azoxymethaneinduced colon carcinogenesis [23]. This plant has been reported to have some analgesic, anti diabetic, antispasmodic, diuretic, antihypertensive, cholesterol lowering, diuretic, antioxidant, antibacterial properties and plays beneficial roles in modern medicine [24-26,18].

M. oleifera is reported to be used for the treatment of rheumatism, ascites, infection, hiccough influenza and internal abscess [10,27]. Moringa leaves have been used to combat malnutrition, especially among infants and nursing mothers and hasten uterine contraction during child birth in pregnant women. It's diuretic, antispasmodic, antiulcer, anti cancer and cholesterol lowering activities have been reported in some countries [28]. .

Most of these studies of the health promoting potentials of moringa leaf were however done using disease-induced animals and the leaf extracts of moringa was often administered to the animals not the whole leaf [29-33]. Little research has been conducted on the health benefits of feeding whole moringa leaf powder supplemented diet to healthy animals.

In this therefore against this background, that this study was undertaken to evaluate the effect of feeding moringa leaf powder supplemented diets on some biochemical indices of healthy rats.

\section{MATERIALS AND METHODS}

\subsection{Moringa Leaf Powder Preparation}

Fresh moringa leaves were collected from a farm in Gboko, Benue State, Nigeria. The leaves were stripped off, washed thoroughly, allowed to drain and then spread thinly on aluminum trays in a well ventilated room $\left(27^{\circ} \mathrm{C} \pm 1\right)$ to dry for five days. The shade dried leaves were ground (hammer mill, Thomas Willey mills, model Ed-5, Germany), sieved with a screen of $2 \mathrm{~mm}$ pore size, placed in amber coloured glass containers and stored in the refrigerator $\left(-4^{\circ} \mathrm{C}\right)$ for blending.

\subsection{Soybean Flour Preparation}

Soybeans were sorted and thoroughly washed in clean tap water and then boiled in excess water for 40 mins. The beans were drained and soaked in excess water for $12 \mathrm{~h}$ and soaking water was changed after every $3 \mathrm{~h}$. Thereafter, the seed coats were removed by rubbing with hands. The cotyledons were separated from the seed coats and the seeds spread on aluminum trays in the sun $\left(32^{\circ} \mathrm{C} \pm 1\right)$ for 2 days for drying. The dried seeds were milled in a commercial attrition mill into flour and sieved with a muslin cloth of $1 \mathrm{~mm}$ pore size [34].

\subsection{Animals}

Twenty-one day old Male Wistar albino rats $(n=25)$, were purchased from faculty of Veterinary Medicine, University of Nigeria, Nsukka, Nigeria. The rats were kept in individual metabolic cages in the Department of Nutrition and Dietetics, University of Nigeria, Nsukka, Nigeria. They fed with normal rat chow for the 7 day period of acclimatization after which they were transferred to the test diets for the 14 day period of the study. The lights in the facility were turned off between 1900 and $0700 \mathrm{~h}$ and the room temperature was maintained at $27^{\circ} \mathrm{C} \pm 1{ }^{\circ} \mathrm{C}$. All studies were pre-reviewed and approved by The University Ethics Committee for Animal Experiments. Procedures for the Animal care conformed to the international laws and Guidelines for the use of Animals in Biomedical Research [35]. Diet and feeding: The diet composition of the different groups is shown in Table 1. Rats had free access to food and distilled water for $24 \mathrm{~h}$ each day throughout the entire study period of 14 days. Feed intake was monitored daily and body weight gain weekly. Feed intake was calculated by the difference between the weight of feed given and left over feed

Blood and tissue collection. At the end of the study period, the animals were sacrificed under light ether anesthesia and blood collected. The blood was collected in heparinized bottles for hematological 
studies. Blood samples taken from non-heparinized bottles were allowed to coagulate to obtain serum. The serum was removed using a Pasteur pipette into another set of tubes, after spinning in a centrifuge (Gallenkamp, England) at 1000rpm for 5 minutes. The serum samples were used in the assay of marker enzymes - alkaline phosphastase (ALP), aspartate aminotransferase (AST) and alanine aminotransferase (ALT) - in addition to total bilirubin and direct bilirubin. The internal organs of the animals were carefully removed, weighed and percentage relative organ weight calculated as shown.

Percentage relative organ weight $=\frac{\text { fresh organ weig } h t(g) \times 100}{\text { liver weight }(g)}$

\subsection{Determination of Haematological Parameters}

\section{Determination of Packed Cell Volume}

The Packed Cell Volume (PCV) was determined by the microhaematocrit method[36] Microcapillary tubes were filled with the blood samples and sealed at one end. The tubes were centrifuged at 10,000rpm for 5 minutes using a microhaematocrit centrifuge. After centrifugation the PCV was read using a microhaematocrit reader.

Determination of Haemoglobin Concentration ( $\mathrm{Hb}$ conc) Haemogloblobin concentrations was determined by cyanomethaemoglobin method [37].

Determination of Red Blood Cell Count (RBC) Red blood cell count was done by the method of Schalm et al. [38]. A $0.02 \mathrm{ml}$ blood sample was pipetted into a clean test tube containing $4 \mathrm{ml}$ of red blood cell diluting fluid to make a 1:200 dilution of the blood sample. The diluted blood sample wad loaded in a Neubauer counting chamber and all red blood cells in the five groups of 16 small squares in the central area of the Neubauer chamber were enumerated using a light microscope at $x 40$ magnification. The number of cell enumerated was multiplied by 10,000 to obtain the red blood cell count per cubic millimeter of blood.

Determination of White blood cell count (WBC) White blood cell count was done using the method of Schalm et al. [38]. A $0.02 \mathrm{ml}$ blood sample was pipetted into a clean test tube containing $4 \mathrm{ml}$ of red blood cell diluting fluid to make a 1:20 dilution of the blood sample. The diluted blood sample was loaded in a Neubauer counting chamber and all white blood cells in the four corner squares were counted using a light microscope at $\times 40$ magnification. The number of cell enumerated was multiplied by 50 to obtain the white blood cell count per cubic millimeter of blood.

\subsection{Serum Enzyme Assay}

The appropriate kits were used for the determination of serum alanine aminotransferase (ALT) and aspartate aminotransferase (AST) according to [39]), alkaline phosphatase (ALP) according to [40]. The enzyme activity was expressed as units/liter computed directly from the absorbance values. Total and direct bilirubin were determined according to [41].

\subsection{Lipid Profile}

Determination of triglycerides (TGs), cholesterol, high density lipoproteins (HDL) and low density lipoproteins (LDL), were carried out using enzymatic colorimetric kits according to [42].

\subsection{Statistical Analysis}

The results were expressed as mean \pm SEM of six animals from each group. The statistical analysis were carried out by one way analysis of variance (ANOVA). P values $<0.05$ were considered significant.

Table1. Rat groups and feed composition

\begin{tabular}{|l|l|l|l|l|l|l|l|l|l|l|}
\hline $\begin{array}{l}\text { Rat } \\
\text { Group }\end{array}$ & $\begin{array}{l}\text { Casein } \\
(\%)\end{array}$ & $\begin{array}{l}\text { Soyflour } \\
(\%)\end{array}$ & $\begin{array}{l}\text { MLP } \\
(\%)\end{array}$ & $\begin{array}{l}\text { Starch } \\
(\%)\end{array}$ & $\begin{array}{l}\text { Sucrose } \\
(\%)\end{array}$ & $\begin{array}{l}\text { Vegetable } \\
\text { oil }(\%)\end{array}$ & $\begin{array}{l}\text { Vitamin } \\
\text { mix }(\%)\end{array}$ & $\begin{array}{l}\text { Mineral mix } \\
(\%)\end{array}$ & $\begin{array}{l}\text { L-methionine } \\
(\%)\end{array}$ & $\begin{array}{l}\text { Total } \\
(\%)\end{array}$ \\
\hline SOY & 18 & 25.6 & - & 38.4 & 7 & 5 & 1 & 4.5 & 0.5 & 100 \\
\hline MORA & 18 & - & 25.6 & 38.4 & 7 & 5 & 1 & 4.5 & 0.5 & 100 \\
\hline MORB & 18 & - & 12.8 & 51.2 & 7 & 5 & 1 & 4.5 & 0.5 & 100 \\
\hline MORC & 18 & - & 6.4 & 57.6 & 7 & 5 & 1 & 4.5 & 0.5 & 100 \\
\hline NORM & 20 & - & - & 62 & 7 & 5 & 1 & 4.5 & 0.5 & 100 \\
\hline
\end{tabular}

SOY: rats fed diet supplemented with 25.6\% Soybean flour, MORA: rats fed diet supplemented with $25.6 \%$ MLP Powder, MORB: rats fed diet supplemented with 12.8\% MLP Powder, MORC: rats fed diet supplemented with $6.4 \%$ MLP Powder 


\section{RESULTS AND DISCUSSION}

Total feed intake and Total body weight gain of rats fed MLP supplemented diets

The effect of MLP supplementation on total feed intake (TFI) and total body weight gain (TBW) of rats is shown in figures 1 and 2. The different diets caused significant $(\mathrm{p}<0.05)$ changes in the TFI and TBW of the animals. Total feed intake increased $(\mathrm{p}<0.05)$ with increasing level of MLP. The TFI for MORA was significantly $(\mathrm{p}<0.05)$ higher $(249.58 \mathrm{~g})$ than the others. The TFI values were $207.04 \mathrm{~g}$ for NORM, 204.77g for MORB and 177.76g for SOY and these values did not differ ( $>0.05$ ). MORC had the least feed consumption of 146.74g. The differences in TBW of the groups were significant $(\mathrm{p}<0.05)$. Total body weight gain increased with increasing level of MLP supplementation. MORA gained the most weight of $30.46 \mathrm{~g}$ but this was not significantly different from TBW of MORB (29.38g) and NORM (25.02g). The least growth was observed in SOY (20.65g).

The high feed intake of MLP based diets by the animals indicated that the taste of the MLP was not objectionable to the animals. The significantly higher increase in the body weight of rats fed moringa supplemented diets might be attributed partly to higher feed intake and also the to the fact that $M$. oleifera is rich in amino acids, vitamins and minerals, particularly iron and phytochemicals[43,1,44]. The protein content of MLP has been reported to be about 30\% [45]. Makkar and Becker [6] reported that moringa leaves contained higher amounts of all the essential amino acids than the amino acid pattern of the FAO reference protein and comparable to those in soybeans. These phytochemicals and nutrients promote health and growth.

In a study using rats, Nambiar and Seshadri [46] observed remarkable feed intake and weight gain in vitamin A deficient rats fed dehydrated moringa leaves compared to synthetic vitamin A. This observation is also in agreement with the findings of [47,48] who also recorded increase in body weight of rats fed moringa leave based diets and extracts. Awodele et al. [49] and Laleye et al. [33], in contrast, reported that there were no statistically significant differences $(p>0.05)$ in the percent weight gain by the animals throughout the course of extract administration in all the doses compared with the control animals. This observation may indicate that the extract did not alter the metabolic processes of the treated animals which may subsequently affect the hormones and body weight [50].

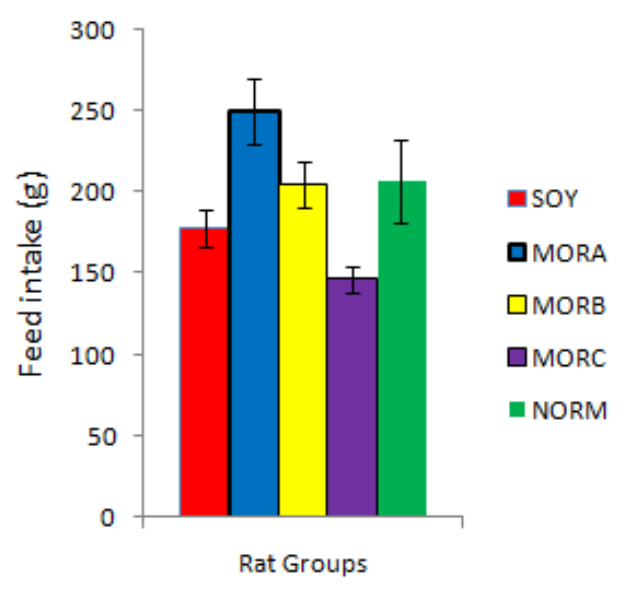

Fig1. Total feed intake ( $g$ ) of rats fed MLP supplemented diets

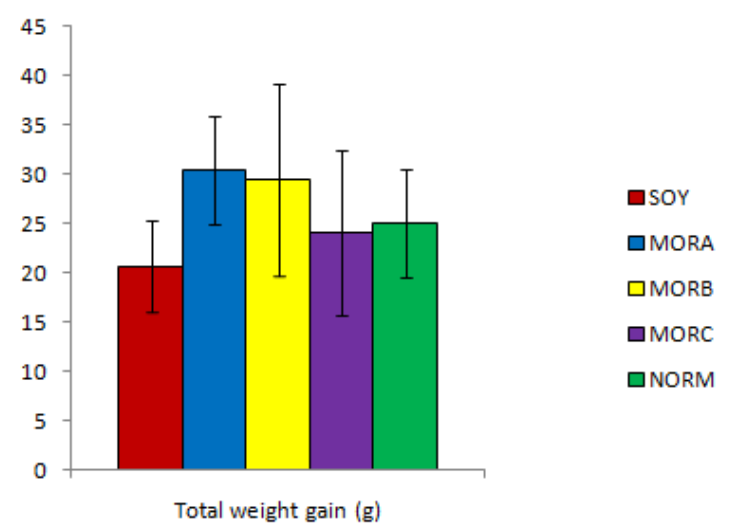

Fig2. Total body weight gain ( $g$ ) of rats fed MLP supplemented diets 


\subsection{Effect of MLP Supplementation on Liver Function Markers of Rats}

The effect of MLP supplementation on liver function markers of rats is shown in Table 2. There were significant $(\mathrm{p}<0.05)$ differences in the alkaline phosphastase (ALP), direct and total bilirubin status among the groups while for the other parameters the changes were not significant. The aspartate aminotransferase (AST) and alanine aminotransferase (ALT) values of the groups ranged from 24.30U/L-30.80 U/L and 28.40U/L -34.80U/L respectively. The AST and ALT values of the MLP fed animals were lower (but not significantly) than the values for either SOY or NORM. The ALP values for the MLP fed animals were equally lower $(27.60 \mathrm{U} / \mathrm{L}-35.00 \mathrm{U} / \mathrm{L})$ than those of SOY $(39.00 \mathrm{U} / \mathrm{L})$ and NORM $(43.60 \mathrm{U} / \mathrm{L})$ but this time the differences were significant at $\mathrm{p}<0.05$. The direct bilirubin values for MLP fed animals ranged from $1.42 \mathrm{mg} / \mathrm{dl}-1.70 \mathrm{mg} / \mathrm{dl}$, while those of SOY and NORM were $2.04 \mathrm{mg} / \mathrm{dl}$ and $1.30 \mathrm{mg} / \mathrm{dl}$ respectively. The differences in these values were significant $(\mathrm{p}<0.05)$. The animals fed MLP based diets exhibited lower values for total bilirubin $(3.56 \mathrm{mg} / \mathrm{dl}-4.24 \mathrm{mg} / \mathrm{dl})$ than for SOY $(5.04 \mathrm{mg} / \mathrm{dl})$ and NORM $(4.28 \mathrm{mg} / \mathrm{dl})$. It is noteworthy that SOY had higher scores than the MLP fed groups in most of the parameters measured; this implied that MLP possesses more liver protective activity than soy bean flour.

The study of different enzyme activities as well as total bilirubin and total protein have been found to be of great value in the assessment of clinical and experimental liver damage[51] and loss of functional integrity of the hepatic cell membrane[52]. The marker enzymes; ALT, AST, and ALP which are originally present in high concentration in the cytoplasm, when there is a hepatic injury, these enzymes leak into blood stream inconformity with the extent of hepatotoxicity [53]. Liver damage is reflected by an increase in the levels of hepato specific enzymes.

It is evident from the result of this experiment that MLP did not have any adverse effect on the liver but could even be said to have some hepatoprotective activity as evident in the significantly lower ALP and TB of MLP fed rat groups. This hepatoprotective function corresponds with the normal relative liver weight observed in the MLP fed animals (see Table 5). Phytochemical analyses have shown that moringa leaves are particularly rich in potassium, calcium, phosphorous, iron, vitamins A and $\mathrm{D}$, essential amino acids, as well as such known antioxidants such as $\beta$-carotene, vitamin $\mathrm{C}$, and flavonoids [54-58]. These may account for its many protective effects on the tissues of the body. Polyphenolic compounds, vitamins $\mathrm{A}, \mathrm{C}$ and $\mathrm{E}$ and selenium in the cell can function as antioxidant and antiprooxidant by scavenging reactive oxygen species via enzymatic and non-enzymatic reactions [59-61]. This compounds, have multiple mechanisms of action, that may be hepatoprotective, including: 1) Antioxidant activity: Flavonoid in general are good free-radical scavengers. 2) Anti lipid prooxidation 3) Induce detoxification systems 4) protection of cell against employed glutation 5) reduction of lukoterin formation from unsaturated free acid 6) Enhanced protein synthesis 7) Stabilization of mastcell 8) Regulation of immuno functions [62].

Saponins are secondary plant metabolites having multiple biological activities including hypocholesterolaemic effects [63,64]. The cholesterol-lowering effects of saponins may be mediated by two mechanisms: decreased intestinal absorption of cholesterol or the enhanced fecal excretion of bile acids or neutral sterols [65]. The high content of saponin in the plant may also aid in lessening the burden on the liver as regards cholesterol metabolism, thereby allowing it, more room to recuperate when challenged. Moringa leaf powder has been reported to contain high amounts of saponins [66,67]. Laleye et al. [33] reported no significant difference in liver marker enzymes between control rats and those administered with moringa leaf extract.

Table2. Effect of MLP supplementation on liver function markers of rats

\begin{tabular}{|l|l|l|l|l|l|}
\hline Rat group & AST (U/L) & ALT (U/L) & ALP (U/L) & Direct Bilirubin mg/dl & Total Bilirubi (mg/dl) \\
\hline SOY & $30.80^{\mathrm{a}} \pm 7.40$ & $34.80^{\mathrm{a}} \pm 7.82$ & $39.00^{\mathrm{ab}} \pm 4.74$ & $2.04^{\mathrm{a}} \pm 0.30$ & $5.04^{\mathrm{a}} \pm 1.13$ \\
\hline MORI A & $26.40^{\mathrm{a}} \pm 5.94$ & $29.20^{\mathrm{a}} \pm 5.45$ & $35.00^{\mathrm{bc}} \pm 7.78$ & $1.42^{\mathrm{c}} \pm .46$ & $3.74^{\mathrm{b}} \pm 0.98$ \\
\hline MORI B & $26.40^{\mathrm{a}} \pm 4.34$ & $29.40^{\mathrm{a}} \pm 5.37$ & $27.60^{\mathrm{c}} \pm 4.33$ & $1.7^{\mathrm{ab}} \pm 0.42$ & $4.24^{\mathrm{ab}} \pm 0.61$ \\
\hline MORI C & $24.30^{\mathrm{a}} \pm 5.13$ & $28.40^{\mathrm{a}} \pm 4.72$ & $30.00^{\mathrm{c}} \pm 8.80$ & $1.64^{\mathrm{b}} \pm 0.31$ & $3.56^{\mathrm{b}} \pm 0.94$ \\
\hline NORM & $26.96^{\mathrm{a}} \pm 5.43$ & $30.60^{\mathrm{a}} \pm 4.62$ & $43.60^{\mathrm{a}} \pm 2.51$ & $1.30^{\mathrm{c}} \pm 0.37$ & $4.28^{\mathrm{ab}} \pm 0.13$ \\
\hline
\end{tabular}

Values on the same column bearing different superscripts are significantly different $(p<0.05)$. 
Table3. Effect of MLP supplementation on serum lipid profile $(\mathrm{mg} / \mathrm{L})$ of rats

\begin{tabular}{|l|l|l|l|l|}
\hline Rat group & Cholesterol & Triglyceride & High density lipoproteins (HDL) & Low density lipoproteins (LDL) \\
\hline SOY & $4.44^{\mathrm{a}} \pm 0.17$ & $1.06^{\mathrm{a}} \pm 0.21$ & $2.22^{\mathrm{a}} \pm 0.32$ & $2.22^{\mathrm{a}} \pm 0.58$ \\
\hline MORA & $4.36^{\mathrm{a}} \pm 0.22$ & $1.00^{\mathrm{a}} \pm 0.14$ & $2.32^{\mathrm{a}} \pm 0.37$ & $2.04^{\mathrm{a}} \pm 0.69$ \\
\hline MORB & $4.40^{\mathrm{a}} \pm 0.07$ & $0.92^{\mathrm{a}} \pm 0.04$ & $2.28^{\mathrm{a}} \pm 0.49$ & $2.12^{\mathrm{a}} \pm 0.49$ \\
\hline MORC & $4.26^{\mathrm{a}} \pm 0.17$ & $1.30^{\mathrm{a}} \pm 0.57$ & $2.22^{\mathrm{a}} \pm 0.69$ & $2.04^{\mathrm{a}} \pm 0.91$ \\
\hline NORM & $4.26^{\mathrm{a}} \pm 0.45$ & $1.18^{\mathrm{a}} \pm 0.13$ & $2.00^{\mathrm{a}} \pm 0.25$ & $2.26^{\mathrm{a}} \pm 0.11$ \\
\hline
\end{tabular}

Values on the same column bearing different superscripts are significantly different $(p \leq 0.05)$.

Table 3 shows the effect of MLP supplementation on the lipid profile of rats. The result reveals that the various diets did not significantly $(p>0.05)$ alter the serum lipid profile of rats. The cholesterol values of the animals ranged from $4.26 \mathrm{mg} / \mathrm{L}-4.44 \mathrm{mg} / \mathrm{L}$, the $\mathrm{LDL}$ values ranged from $2.04 \mathrm{mg} / \mathrm{L}-$ $2.26 \mathrm{mg} / \mathrm{L}$, while HDL cholesterol ranged from $2.00 \mathrm{mg} / \mathrm{L}-2.32 \mathrm{mg} / \mathrm{L}$.

Total serum cholesterol is really an indicator of the amount of the free radical damage in the body. Higher the free radical level, higher the body needs to produce cholesterol internally from liver to act as an antioxidant and free radical scavenger [68]. Higher level of LDL cholesterol means greater risk of atherosclerotic heart disease while higher level of HDL cholesterol means lower risk of coronary heart disease [69,70]. Significant lowering of total cholesterol, triglycerides, LDL-cholesterol and raise in HDL cholesterol therefore is a very desirable biochemical state for prevention of atherosclerosis and ischaemic conditions [71,72].

Worthy of note is the reduction of LDL by MLP (though insignificant), it could therefore be said that MLP does not contain compounds that activate free radical production in the body but contains compounds that stabilize lipid profile of animals. Seriki et al. [73] observed that there was no significant effect $(p>0.05)$ in the lipid profile status of subjects fed with moringa leaf powder based diet and those who were not. The result of this study is in contrast to the result from many researchers who reported the hypocholesteromic activity of moringa leaves [74,75,33]. The discrepancy could be attributed to the fact that most of these researchers used animals induced with hypercholestromia rather than healthy animals. It could be inferred that moringa leaf powder lowers the cholesterol level of animals with high cholesterol but this is not so for normal rats.

Table4. Effect of MLP supplementation on the haematological indices of rats

\begin{tabular}{|l|l|l|l|l|}
\hline Rat group & PCV $(\%)$ & $\mathrm{Hb}(\mathrm{g} / \mathrm{dl})$ & $\mathrm{RBC} \times 10^{6} / \mathrm{mm}^{3}$ & $\mathrm{WBC} \times 10^{3} / \mathrm{mm}^{3}$ \\
\hline SOY & $41.40^{\mathrm{ab}} \pm 2.70$ & $14.36^{\mathrm{ab}} \pm \pm 0.71$ & $3.20^{\mathrm{ab}} \pm 0.17$ & $9.73^{\mathrm{c}} \pm 0.62$ \\
\hline MORA & $38.40^{\mathrm{b}} \pm 2.70$ & $13.64^{\mathrm{b}} \pm 1.07$ & $3.09^{\mathrm{ab}} \pm 0.65$ & $10.91^{\mathrm{ab}} \pm 0.37$ \\
\hline MORB & $41.00^{\mathrm{ab}} \pm 2.12$ & $14.36^{\mathrm{ab}} \pm 0.33$ & $2.88^{\mathrm{b}} \pm 0.17$ & $10.56^{\mathrm{ab}} \pm 0.51$ \\
\hline MORC & $41.00^{\mathrm{ab}} \pm 1.00$ & $14.26^{\mathrm{ab}} \pm 0.27$ & $3.44^{\mathrm{a}} \pm 0.43$ & $10.37^{\mathrm{bc}} \pm 0.82$ \\
\hline NORM & $42.20^{\mathrm{a}} \pm 1.79$ & $14.74^{\mathrm{a}} \pm 0.46$ & $3.05^{\mathrm{ab}} \pm 0.38$ & $11.60^{\mathrm{a}} \pm 0.25$ \\
\hline
\end{tabular}

Values on the same column bearing different superscripts are significantly different $(p \leq 0.05)$.

Table 4 shows the effect of MLP supplementation on the haematological indices of rats. There were significant $(\mathrm{p} \leq 0.05)$ differences in all the parameters evaluated. The packed cell volume of NORM $(42.20 \%)$ was not significantly ( $>0.05)$ different from that of other groups except for MORA (38.40\%). The haemoglobin concentration also followed the same trend with MORA exhibiting the lowest value of $13.64 \mathrm{~g} / \mathrm{dl}$. The RBC values ranged from $2.88 \times 10^{6} / \mathrm{mm}^{3}-3.4410^{6} / \mathrm{mm}^{3}$ while WBC values from $9.73 \times 10^{3} / \mathrm{mm}^{3}-11.60 \times 10^{13} / \mathrm{mm}^{3}$. MORB had the least value for RBC while MORC had the least value for WBC.

The result of the haematological parameters of rats shows that at $25.6 \%$ level of supplementation, there was a slight decrease in the PCV and $\mathrm{Hb}$ values of rats. These values were however within range of values for normal rats [76]. In contrast, Otitoju, et al. [77], administered moringa leaf extract to rats in a sub toxicity study and they reported a general increase in the haematological parameters in a dose dependent manner. Olugbemi et al. [78], however observed no significant differences between $\mathrm{PCV}, \mathrm{Hb}$ and $\mathrm{RBC}$ of broiler chickens fed with moringa supplemented diets and those fed the control diets.

Phytochemicals are known to exhibit different biochemical and pharmacological actions in different species of animals when ingested. These actions range from cell toxicity to cell protective effects [79]. 
The result of this study implied that MLP supplementation up to $25.6 \%$ did not induce negative changes in the haematological parameters of rats.

Table5. Effect of MLP supplementation on percentage relative organ weight (\%) of rats

\begin{tabular}{|l|l|l|l|l|l|}
\hline Rat group & Liver & Spleen & kidney & lung & heart \\
\hline SOY & $2.99^{\mathrm{b}} \pm 0.54$ & $0.50^{\mathrm{ab}} \pm 0.12$ & $0.88^{\mathrm{a}} \pm 0.18$ & $0.57^{\mathrm{b}} \pm 0.14$ & $0.43^{\mathrm{b}} \pm 0.06$ \\
\hline MORI A & $3.58^{\mathrm{ab}} \pm 0.15$ & $0.58^{\mathrm{a}} \pm 0.09$ & $0.85^{\mathrm{a}} \pm 0.04$ & $0.70^{\mathrm{ab}} \pm 0.03$ & $0.52^{\mathrm{a}} \pm 0.05$ \\
\hline MORI B & $3.89^{\mathrm{a}} \pm 0.77$ & $0.43^{\mathrm{b}} \pm 0.05$ & $0.80^{\mathrm{a}} \pm 0.17$ & $0.57^{\mathrm{b}} \pm 0.16$ & $0.41^{\mathrm{bc}} \pm 0.07$ \\
\hline MORI C & $3.55^{\mathrm{a}} \pm 0.70$ & $0.55^{\mathrm{ab}} \pm 0.15$ & $0.83^{\mathrm{a}} \pm 0.14$ & $0.83^{\mathrm{a}} \pm 0.31$ & $0.41^{\mathrm{bc}} \pm 0.07$ \\
\hline NORM & $3.32^{\mathrm{ab}} \pm 0.36$ & $0.44^{\mathrm{ab}} \pm 0.02$ & $0.73^{\mathrm{a}} \pm 0.03$ & $0.62^{\mathrm{ab}} \pm 0.03$ & $0.33^{\mathrm{c}} \pm 0.03$ \\
\hline
\end{tabular}

Values on the same column bearing different superscripts are significantly different $(p \leq 0.05)$.

Table 4 shows the effect of MLP supplementation on percentage relative organ weight of rats. There were significant $(p<0.05)$ variations in percentage relative organ weight as a result of differences in diet except for kidney. The $\%$ relative liver weight of the animals varied from $2.99-3.89$. There was no significant difference in the liver weight between the MLP fed animals and the ones fed normal diet. There was also no significant difference in the \% relative spleen weight of rats fed the normal diet (0.44) and those fed MLP diets (0.43-0.58). The differences in the values of the relative kidney weight (0.73-0.88) among the groups were not significant. The moringa diets did not also cause any significant change in the relative lung weight of the rats in relation to normal diet fed ones. In the case of the heart however, rats fed MORA had significantly $(p<0.05)$ elevated $\%$ relative heart weight $(0.52)$ than other MLP fed groups (0.41) and the normal diet fed ones (0.33).

The liver and kidney play important roles in the detoxification and excretion of most toxic materials from the body; hence they are affected by the presence of toxins or anti nutrients in the diets. These observed effects imply that MLP supplementation up to $25.6 \%$ did not cause any deleterious effect in most organs of the animals. At a high level of supplementation $(25.6 \%)$ however it could cause enlargement of the heart. Moringa leaves have been reported to contain very low levels of toxins and antinutrients [66]. Moringa leaf powder could therefore be safe for consumption.

\section{CONClusion}

The result of this study showed that moringa leaf powder supplementation in the diet of rats had no serious negative effect on the biochemical indices of rats studied rather it promoted growth of the animals and exhibited some hepatoprotective properties as shown by lower values of ALT, direct and total bilirubin levels of the rats. Moringa leaf powder could therefore be said to be safe for consumption not only as a source of nutrients but also of health promoting phytochemicals.

\section{REFERENCES}

[1] Fahey, J.W., "Moringa oleifera: A Review of the Medical Evidence for its Nutritional, Therapeutic, and Prophylactic Properties. Part 1", Trees for Life (2005), http://www.TFLJournal.org/article.php/200512 01124931586.

[2] Fuglie, L.J., the Miracle Tree: The Multiple Attributes of Moringa. Church World Service, Dakar, (2001), $172 \mathrm{pp}$

[3] Monica premi, H.K., B. Sharma, C. Sarkar and C. Singh, 2010. Kinetics of drumstick leaves (Moringa oleifera) during convective drying. African Journal of Plant Science, 4(10): 391-400.

[4] Vinoth, B., R. Manivasagaperumal, R. and S. Balamurugan, S., Phytochemical analysis and antibacterial activity of Moringa Oleifera Lam. International Journal of Research in Biological Sciences, 2(3): 98-102, (2012)

[5] Martin, F.W., Ruberte, R.M, and Meitzner, L.S., Edible Leaves of the Tropics. 3rd Ed. Educational Concerns for Hunger Organization, Inc., N. Ft. Meyers, Florida, (1998), 194 pp.

[6] Makkar, H.P.S. and Becker, K. Nutrients and antiquality factors in different morphological parts of the Moringa oleifera tree. Journal of Agricultural Science, Cambridge 128: 311-322, (1997)

[7] Moyo, B., Masika,P.J., Hugo, A and Muchenje, V., Nutritional characterization of Moringa (Moringa oleifera Lam.) leaves. African Journal of Biotechnology 10(60):12925-12933, (2011).

[8] Sabale, V., Patel, V., Paranjape, A., Arya, C., Sakarkar, S. N. and Sabale, P. M., "Moringa oleifera (Drumstick): An Overview", Pharmacognosy Reviews, 2(4): 7-13, (2008).

[9] Joshi, P and Mehta, D., Effect of dehydration on the nutritive value of drumstick Leaves. Journal of Metabolomics and Systems Biology, 1(1):5 -9, (2010) 
[10] Anwar, F., Latif, S., Ashraf, M. and Gilani, A.H., Moringa oleifera: A food plant with multiple medicinal uses. Phytother. Res. 21:17-125, (2007).

[11] Mensah, J.K., Ikhajiagbe, B., Edema,N.E. and Emokhor J., Phytochemical, nutritional and antibacterial properties of dried leaf powder of Moringa oleifera (Lam) from Edo Central Province, Nigeria. J. Nat. Prod. Plant Resour. 2 (1):107-112, (2012).

[12] Oluduro, A.O., Evaluation of antimicrobial properties and nutritional potentials of Moringa oleifera Lam. leaf in South-Western Nigeria. Malaysian Journal of Microbiology, 8(2): 59-67, (2012).

[13] Lako,J., Trenerry, V.C., Wahlqvist, M., Wattanapenpaiboon, N., Sotheeswaran,S. and Robert Premier, R., Phytochemical flavonols, carotenoids and the antioxidant properties of a wide selection of Fijian fruit, vegetables and other readily available foods. Food Chemistry, 101(4): 1727-1741,(2007)

[14] Sung, J. and Lee, J., Antioxidant and antiproliferative activities of grape seeds from different cultivars. Food Sci. Biotechnol. 19: 321-326, (2010).

[15] Zhang,Y., Gan,R., Li, S., Yue Zhou, Y., Li, A., Xu, D and Li,H., Antioxidant Phytochemicals for the Prevention and Treatment of Chronic Diseases. Molecules 20(12):21138-21156, (2015).

[16] Mbikay, M., Therapeutic potential of Moringa oleifera leaves in chronic hyperglycemia and dyslipidemia: A review. Front. Pharmacol. 3:1-12, (2012).

[17] Abdulrahman, L.A. and Haddad, A.E.,The Antidiabetic Effect of Low Doses of Moringa oleifera Lam. Seeds on Streptozotocin Induced Diabetes and Diabetic Nephropathy in Male Rats. BioMed Research International, (2015). http://dx.doi.org/10.1155/2015/381040

[18] Sreelatha, S., Jeyachitra, A. and Padma, P.R., Antiproliferation and induction of apoptosis by Moringa oleifera leaf extract on human cancer cells. Food Chem. Toxicol. 49(6):1270-1275, (2011).

[19] Berkovich, L., Earon, G., Ron, I., Rimmon, A., Vexler, A. and Lev-Ari, S., Moringa oleifera aqueous leaf extract down-regulates nuclear factor- kappaB and increases cytotoxic effect of chemotherapy in pancreatic cancer cells. BMC Complement. Altern. Med. 13:212-219, (2013).

[20] Sathya, T.N., Aadarsh, P., Deepa, V. and Balakrishna, M.P., Moringa oleifera Lam. leaves prevent cyclophosphamide induced micronucleus and DNA damage in mice. International Journal of Phytomedicine, 2:147-154, (2010).

[21] Fakurazi, S., Hairuszah, I. and Nanthini, U., Moringa oleifera Lam prevents acetaminophen induced liver injury through restoration of glutathione level. Food Chem Toxicol. 46:2611, (2008).

[22] Chadamas, P., Kupradinun, P.,Tuntipopipat, S. and Butryee, C., Nutritive evaluation and effect of Moringa oleifera Lam pod on clastogenic potential in the mouse. Asian Pac. J. Cancer Prev. 11:627-632, (2010).

[23] Budda, S., Butryee, C., Tuntipopipat, S., Rungsipipat, A., Wangnaithum, S., Lee, J.S. and Kupradinun, P., Suppressive effects of Moringa oleifera Lam pod against mouse colon carcinogenesis induced by azoxymethane and dextran sodium sulfate. Asi an Pac. J. Cancer Prev. 12:3221-3228, (2011).

[24] Dièye, A.M., Sarr, A., Diop, S.N., Ndiaye, M., Sy, G.Y., Diarra, M., Faye, B. Medicinal plants and the treatment of diabetes in Senegal: Survey with patients. Fundam. Clin. Pharmacol. 22, 211-216, (2008).

[25] Mehta, J., Shukla, A., Bukhariya, V., Charde, R. and Road, R., The magic remedy of Moringa oleifera: An overview. Int. J. Biomed. Adv. Res. 2:1-13, (2011).

[26] Farooq, F., Rai, M., Tiwari, A., Khan, A.A., Farooq, S., Medicinal properties of Moringa oleifera: An overview of promising healer. J. Med. Plants Res. 6:4368-4374, (2012)

[27] Mishra, G., Singh, P., Verma, R., Kumar, S., Srivastav, S., Jha, K.K. and Khosa, R.L.,.Traditional uses, phytochemistry and pharmacological properties of Moringa oleifera plant: An overview. Der Pharmacia Lettre, 3:141-164, (2011).

[28] Thilza, L. B., Sanni, S., Zakari, A. I., Sanni, F. S., Talle, M. And Joseph, B. M., In vitro Antimicrobial activity of water extract of Moringa oleifera leaf stalk on bacteria normally implicated in eye diseases. Academia arena 2(6): 80-82, (2010).

[29] Pari, L. and Kumar, N.A. Hepatoprotective activity of Moringa oleifera on antitubercular drug-induced liver damage in rats. J. Med. Food 2002, 5, 171-177, (2002).

[30] Pankaj, G., Jain, S. D., Patil, N. G., Haswani, M. V. Girase, Surana, S.J., Hypolipidemic activity of Moringa oleifera Lam., Moringaceae, on high fat diet induced hyperlipidemia in albino rats. Brazilian Journal of Pharmacognosy, 20(6): 969-973, (2010).

[31] Chatterjee, P.K., Vinodini, N.A., Amemarsoofi, A., Nayanatara, A.K., Pai, S.R. and Suman, V.B. Hypolipidemic effect of Moringa oleifera leaf extract in cadmium exposed rats. International Journal of Innovative Research in Science, Engineering and Technology, 2(9):4718-23, (2013).

[32] Manal, M. A., Vergara-Jimenez, M., Murillo, A.G., Norris, G.H., Blesso, C.N. and Fernandez, M.L., Moringa Leaves Prevent Hepatic Lipid Accumulation and Inflammation in Guinea Pigs by Reducing the Expression of Genes Involved in Lipid Metabolism international journal of molecular sciences 18 (7) doi:10.3390/ijms18071330 
[33] Laleye, O.A.F., Azando, E.V.B., Olounlade, A.O., Tohouegnon, T., Laleye, A.and Ahissou, H., Evaluation of antihyperglycemic, antiradical and acute oral toxicity activities of aqueous leaves extract of Moringa oleifera Lam (Moringaceae) from Benin in normal rats. Afr. J. Biotechnol.16 (27):1513-1519, (2017).

[34] Enwere, N.J., Enhancing the quality of food through preservation and processing. In: Foods of plant origin. Afro-orbis publications Ltd, Nsukka, Nigeria, 1998.pp 181-214

[35] Giles, A.R., Guidelines for the use of animals in biomedical research. Thrombosis and Haemostasis 58: 1079-1084, (1987

[36] Coles, E.H. Veterinary clinical pathology. 4th edn. W.B.S Saunders Co. Philadelphia, (1986) pp15-19

[37] ICSH. International Committee for Standardization in Haematology. Recommendations for haemoglobinometry in human blood. British Journal of Haematology 13 (suppl.) 7, (1967).

[38] Schalm, O.W., Jain, N.C. and Carroll, E.J., Veterinary hematology. 3rd edn. Lea and Febiger, Philadelphia, USA. (1975). pp 807

[39] Reitman, S. and Frankel, S. A., colorimetric method for the determination of serum glutamic oxalacetic and glutamicpyruvic transaminases. Am J Clin Pathol 28:56-63, (1957)

[40] Belfield, A. and Goldberg, D.M., Revised assay for serum phenyl phosphatase activity using 4-aminoantipyrine. Enzyme 12:561-573, (1971).

[41] Walters, M.I. and Gearde, A., Ultra micro method for determination of conjugate and total bilirubin in serum or plasma. Microchem J 15:231-234, (1970).

[42] Tietz. N.W.Fundamental of clinical chemistry. $2^{\text {nd }}$ Edn.W.B.Saunders,Philadelphia, pp:878 -878.(1976).

[43] Booth, F.E. and Wickens, G.E., Non-timber uses of selected arid zone trees and shrubs in Africa. FAO conservation guide, pp. 92-101, (1988).

[44] Mori, S., Cameldi, I. and Pardini, A., Moringa oleifera: A promising multipurpose tree for tropical and subtropical areas. Associazione Scienze Agrarie Tropicali 1:1-2, (2009)

[45] Oduro, I., Ellis, W. O. and Owusu, D., Nutritional potential of two leafy vegetables: Moringa oleifera and Ipomoea batatas leaves. Scientific Research and Essay 3 (2): 57-60, (2008).

[46] Nambiar, V. S. and Seshadri, S., Bioavailability of beta carotene from fresh and dehydrated drumstick leave s in a rat model. Plant Foods for Human Nutrition 56, (1): 83-95, (2001).

[47] Osman, H.M., Shayoub, M.E. and Babiker, E.M., (2012).The Effect of Moringa oleifera leaves on blood parameters and body weights of albinno rats and rabbits. Jordan Journal of Biological Sciences, Vo. 5, No $3, \operatorname{Pg} 147-150$

[48] Ekundina, V.O., Ebeye O.A., Oladele A.A. and OSHAM, G.O., Hepatotoxic and nephrotoxic effects of moringa oleifera leaves extract in adult wistar rats. Journal of Natural Sciences Research, 5(3):110-117, (2015).

[49] Awodele, O., Oreagba, I.A., Odoma,S., Teixeira da Silva, J,A. and Osunkalu, V.O., Toxicological evaluation of the aqueous leaf extract of Moringa oleifera Lam. (Moringaceae). Journal of Ethnopharmacology, 139:330-336, (2012).

[50] Cajuday,A.L., Poscidio, L.G., Effects of Moringa oleifera Lam. (Moringaceae) on the reproduction of male mice (Musmusculus).Journal of Medicinal Plants Research 4 (12):1115-1121, (2010).

[51] Zafar, R. and Mujahid, A. S. (1998). Anti-hepatotoxic effects of root and root callus extracts of Cichorium intybus L. Journal of Ethnopharmacology 63: 227-231.

[52] Kalegari, M.; Gemin, C.A.; Araújo-Silva, G.; Brito, N.J.; López, J.A.; Oliveira Tozetto, S.D.; das Graças Almeida, M.; Miguel, M.D.; Stien, D.; Miguel, O.G., Chemical composition, antioxidant activity and hepatoprotective potential of Rourea induta Planch. (Connaraceae) against $\mathrm{CCl}_{4}$-induced liver injury in female rats. Nutrition, 6:713-718, (2014).

[53] Azab,S.S., Abdel-Daim, M., Eldahshan, O.A., Phytochemical, cytotoxic, hepatoprotective and antioxidant properties of Delonix regia leaves extract. Medicinal Chemistry Research (2012) DOI 10.1007/s00044012-0420-4

[54] Bennett, R.N., Mellon, F.A., Foidl, N., Pratt, J.H., Dupont, M.S., Perkins, L. and Kroon, P.A., Profiling glucosinolates and phenolics in vegetative and reproductive tissues of the multipurpose trees Moringa oleifera L. (Horse radish tree) and Moringa stenopetala L. Journal of Agriculture and Food Chemistry 51: 3546-3553, (2003). 
[55] Aslam, M., Anwar, F., Nadeem, R., Rashid, U., Kazi, T.G. and Nadeem, M., Mineral composition of Moringa oleifera leaves and pods from different regions of Punjab, Pakistan. Asian Journal of Plant Sciences 4(4):417-421, (2005).

[56] Manguro, L. O. and Lemmen P. Phenolics of Moringa oleifera leaves. Nat. Prod. Res. 21, 56-68, (2007).

[57] Amaglo, N. K., Bennett, R. N., Lo Curto, R. B., Rosa, E. A. S., Lo Turco, V., Giuffrid, A., Lo Curto, A., Crea, F. and Timpo, G. M., Profiling selected phytochemicals and nutrients in different tissues of the multipurpose tree Moringa oleifera L., grown in Ghana. Food Chem. 122, 1047-1054, (2010).

[58] Gowrishankar, R., Kumar, M., Menon, V., Divi, S. M., Saravanan, M., Magudapathy, P., Panigrahi, B. K., Nair, K. G., and Venkataramaniah, K., Trace element studies on Tinospora cordifolia (Menispermaceae), Ocimum sanctum (Lamiaceae), Moringa oleifera (Moringaceae), and Phyllanthus niruri (Euphorbiaceae) using PIXE. Biol. Trace Elem. Res., 133, 357-363, (2010).

[59] Marja, P.K., Anu, I.H., Heikki, J.V., Jussi-Pekka, R. Kalevi, P. Tytti, S.K. and Marina, H., Antioxidat activity of plant extracts containing phenolic compounds. Journal of Agriculture and Food Chemistry, 47: 3945-3962, (1999).

[60] Sakihama, Y., Cohen, M.F., Grace, S.C. and Yamasaki, H., Plant phenolic antioxidant and prooxidant activities: phenolics-induced oxidative damage mediated by metals in plants. Toxicolog,y 177: 67-80, (2002).

[61] Pyo, Y.H., Lee, T.C., Logendra, L. and Rosen, R.T., Antioxidant activity and phenolic compounds of Swiss chard (Beta vulgaris subspecies cycla) extracts. Food Chemistry 85: 19-26, (2004).

[62] Papetti, A., Daglia, M. and Gazzani, G., Anti-and prooxidant activity of water soluble compounds in Cichorium intybus var. Silvestre. Journal of Pharmaceutical and Biomedical Analysis, 30: 939-945, (2002).

[63] Oleszek, W. and Marston, A., Saponins in food, feedstuffs and medicinal plants. Dordrecht: Kluwer Academic Publishers, (2000).

[64] Berhow, M.A., Bin Kong, S., Vermillion, K.E.and Duval, S.M., Complete quantification of group A and group B soyasaponins in soybeans. J Agric Food Chem 54(6) , 2035-2044, (2006)

[65] Lee, S., Simons, A.L., Murphy, P.A. and Hendrich, S., Soyasaponins lowered plasma cholesterol and increased fecal bile acids in female golden Syrian hamsters. Exp Biol Med., 230(7):472-8,(2005).

[66] Makkar, H. P. S. and Becker, K., Nutritional value and antinutritional component of whole and ethanol extracted Moringa Oleifera leaves. Journal of Feed Science and Tecnology, 63, 211-228, (1996).

[67] Indriasari, Y., Wignyanto and Kumalaningsih, S., Effect of blanching on saponins and nutritional content of moringa leaves extract. Journal of Food Research, 5(3): 55-60, (2016)

[68] Bansal, M.P. and Jaswal, S., Hypercholesterolemia Induced Oxidative Stress Is Reduced in Rats with Diets Enriched with Supplement from Dunaliella salina Algae. American Journal of Biomedical Sciences, 1(3): 196-204 (2009).

[69] Nimal, R.W.M. and Sarwar, G.G., Nutritional and health effects of dietary fats. Pakistan Journal of Nutrition 3(4): 205-212, (2004).

[70] Ajayi, O.B. and Ajayi, D.D., Effect of oilseed diets on plasma lipid profile in albino rats. Pakistan Journal of Nutrition, 8( 2): 116-118, (2009).

[71] Jouad, H., Lemhadri, A., Maghrani, M., Zeggwah, N. and Eddouks, M., Cholesterol lowering activity of the aqueous extract of Spergularia purpurea in normal and recent onset diabetic rats. Journal of Ethnopharmacology, 87: 43-49, (2003).

[72] Daisy, P., Eliza, J. and Farook, K.A.M., A novel dihydroxy gymnemic triacetate isolated from Gymnema sylvestre possessing normoglycemic and hypolipidemic activity on STZ-induced diabetic rats. Journal of Ethnopharmacology 126: 339-344, (2009).

[73] Seriki, S.A., Omolaso, B., Adegbite, O.A., Audu, A.I., Effect of Moringa oleifera on lipid profile, blood pressure and body mass index in human. European Journal of Pharmaceutical and Medical Research, 2(7), 94-99, (2015)

[74] Ghasi, S., Nwobodo, E. and Ofili, J.O., Hypocholesterolemic effects of crude extract of leaf of Moringa oleifera Lam in high-fat diet fed wistar rats. Journal of Ethnopharmacology, 69:21-22, (2000).

[75] Chumark,P., Khunawat, P., Sanvarinda, Y., Phornchirasilp, S., Morales, N.P., Phivthongngam, L., Ratanachamnong, P., Srisawat, S. and Pongrapeeporn, K.S., The in vitro and ex vivo antioxidant properties, hypolipidaemic and antiatherosclerotic activities of water extract of Moringa oleifera Lam. leaves. $J$ Ethnopharmacol., 116(3):439-46, (2008).

[76] The Rat Fan Club. Normal Lab Values, (2014). http://www.ratfanclub.org/values.html 
[77] Otitoju, O., Nwamarah, J.U., Otitoju, G.T.O., Okorie, A.U., Stevens, C. and Baiyeri, K.P., Effect of Moringa oleifera aqueous leaf extract on some haematological indices in Wistar rats. Chemical and Process Engineering Research, 18:26-30, (2014)

[78] Olugbemi, T.S, Mutayoba, S.K. and Lekule, F.P., Effect of Moringa oleifera inclusion in cassava based diets fed to broiler chickens. International Journal of Poultry Science 9(4): 363-367, (2010).

[79] Trease, G.E. and Evans, W.C. Phenols and phenolic glycosides. In: Pharmacognosy, 13th edn. Biliere Tindall, London, (1996). pp832-833

Citation: A. Ifeyinwa S, "Effect of Moringa Leaf Powder Supplementation on Some Biochemical Indices of Rats", International Journal of Research Studies in Biosciences (IJRSB), vol. 5, no. 9, pp. 48-58, 2017. http://dx.doi.org/10.20431/2349-0365.0509009

Copyright: (C) 2017 Authors. This is an open-access article distributed under the terms of the Creative Commons Attribution License, which permits unrestricted use, distribution, and reproduction in any medium, provided the original author and source are credited. 